Domeniko Kvartuč

Valentino Kuzelj ${ }^{2}$

dr. sc. Tajana Petrović ${ }^{3}$

\title{
ULOGA NACIONALNIH SOCIJALNIH DRŽAVA U OČUVANJU I ZAŠTITI SOCIJALNIH VRIJEDNOSTI U KONTEKSTU NEOLIBERALNOG GLOBALNOG PORETKA*
}

Pregledni rad / Review paper

UDK/UDC: $342.22: 327$

DOI: 10.51650/ezrvs.15.3-4.6

Primljeno / Received: 9/11/2021

Prihvaćeno / Accepted: 6/12/2021

\begin{abstract}
Globalizacija, kao proces koji teži sveobuhvatnosti i jedinstvenosti svijeta, nameće složeno pitanje o načinima sukobljavanja s ekonomskim nejednakostima kao posljedicom neoliberalnog modela integracije svjetskoga tržišta. Imajući na umu restrukturacijsku prirodu tog procesa, koji se odvija na više razina, dolazi se do zaključka kako nastali odnosi u svjetskoj trgovinskoj mreži umanjuju značaj financijske suverenosti nacionalnih država. Sobzirom na to, ekonomske nejednakosti se perpetuiraju, a socijalni instrumenti nacionalnih država su blokirani zbog umreženosti u globalno tržište koje se odvija po obrascu neoliberalne paradigme. U radu se izlažu razine na kojima se odvija integracija globalnoga tržišta (makro, mezo i mikro) te se ističu različiti učinci globalizacijskoga procesa na razvijene (zapadne) demokracije, tržišna gospodarstva u nastajanju, zemlje u razvoju te države post-tranzicije iz socijalizma u demokraciju. Dodatno, ističe se utjecaj ekonomskih procesa i kriza na ustavne poretke nacionalnih država, što može rezultirati „prešutnom“ izmjenom ustavnih struktura pojedinih država u smjeru rastakanja uloge zakonodavnog tijela (kao izabranog predstavništva građana) pri kreiranju ekonomskih, fiskalnih i socijalnih politika. Naposljetku se ukazuje kako je, s obzirom na nemogućnost jedinstvene regulacije svjetskoga tržišta, mehanizme za suzbijanje negativnih (socijalnih i ekonomskih) posljedica globalizacijskoga procesa potrebno pronaći unutar okvira nacionalnih socijalnih država.
\end{abstract}

Ključne riječi: socijalna država, globalizacija, neoliberalizam, ekonomske nejednakosti, socijalne vrijednosti.

\footnotetext{
1 Filozofski fakultet Sveučilišta u Zagrebu; e-mail: domeniko.kvartuc01@gmail.com

2 Pravni fakultet Sveučilišta u Zagrebu; e-mail: valentino.kuzelj01@gmail.com

3 Porezna uprava, Ministarstvo financija, Koprivnica; vanjska suradnica na Odjelu za ekonomiju Sveučilišta Sjever, e-mail: tajana.petrovich@gmail.com

* Ovaj se rad dijelom temelji na istoimenom radu Domenika Kvartuča i Valentina Kuzelja nagrađenom godišnjom nagradom „Krešimir Kufrin“ Odsjeka za sociologiju Filozofskog fakulteta Sveučilišta u Zagrebu za ak. god. 2020./2021. te predstavlja njegovu dopunjenu i proširenu verziju.
} 


\section{Uvod}

Proces povezivanja svijeta započinje na pragu novog vijeka otkrićem Amerike (1492. godine), a kulminira u 20. stoljeću kroz stvaranje globalnog tržišta. ${ }^{4}$ Tako je sve donedavno socijalna država (kao skup djelatnosti države usmjeren ispravljanju nejednakosti i nepovoljnih društvenih posljedica generiranih nereguliranim, tzv. slobodnim tržištem) promatrana kao gotovo isključivo nacionalni koncept $s$ visokom razinom regulatorne autonomije $u$ odnosu na definiranje makroekonomskog okvira te vođenje monetarnih, fiskalnih i socijalnih politika. ${ }^{5}$ Cilj mjera socijalne države ogleda se u uspostavi opće dobrobiti društva, s obzirom da „koncept dobrobiti“ obuhvaća potrebe od središnje važnosti za pojedince (građane) te se sustav javne ili opće dobrobiti odnosi na potrebe koje javni sektor financira ili pruža u vidu dohodovnih transfera ili javnih (socijalnih) usluga. Razina javne potrošnje za socijalne mjere i usluge ima direktan utjecaj na zadovoljstvo građana, barem u mjeri u kojoj politike socijalne države uživaju potporu elektorata te, samim time, visoku razinu legitimnosti u društvu. ${ }^{6}$ Suvremeno stanje u svijetu pokazalo je kako se društveni razvoj ne može postići ekonomskim razvitkom koji zanemaruje socijalne komponente. ${ }^{7}$

Stoga je potrebno promotriti narav globalizacijskoga procesa kao isključivo ekonomske integracije svjetskoga tržišta (2. poglavlje); restrukturaciju ekonomskih nejednakosti pod utjecajem zagovornika neoliberalne paradigme (3. poglavlje); te, naposljetku, važnost i značaj ostvarenja ideala socijalne pravde u okviru nacionalnih socijalnih država za osiguranje dostojnog života građana te očuvanje povjerenja u ustavne poretke demokratskih i socijalnih država (4. poglavlje). Umjesto zaključka, apostrofira se potreba aktivnije predanosti nacionalnih država ostvarenju socijalne pravde, u svrhu izgradnje globalizacije solidarnosti.

\section{Umreženost svjetskoga tržišta vođena idealima neoliberalne dogme}

Proučavanju suvremenog globalnog društva valja pristupiti kroz podjelu njegove analize na makro, mezo i mikro razinu. Na makro razini izdvajaju se ekonomski procesi trgovine bez granica kroz transakcije financija i kapitala, koji se odvijaju uz pomoć institucionalne strukture međunarodnih financijskih organizacija, ponajprije Međunarodnog monetarnog fonda (engl. International Monetary Fund, u nastavku: IMF), Svjetske banke (engl. World Bank, u nastavku: WB) te Svjetske trgovinske organizacije (engl. World Trade Organization). Proizlazi kako sustav svjetskoga tržišta nije isključivo samoregulirajući, spontan niti isključivo ekonomski. Na mezo razini izdvajaju se ključni trgovci i posrednici u globalnoj privredi te regionalna udruženja poput Europske unije (u nastavku: EU) ili Sjevernoameričkog sporazuma o slobodnoj trgovini (engl. North American Free Trade Agreement, u nastavku: NAFTA) pod čijim okriljem dolazi do integracije i koncentracije kapitala, a njihovo sudjelovanje u organizaciji i upravljanju tržištem utječe na stvaranje i održavanje globalne ekonomije. Naposljetku, mikro

\footnotetext{
4 Barišić, P., Does Globalization Threaten Democracy?, Synthesis philosophica, Vol. 46, br. 2, 2008., str. 298.

5 Mishra, R., (2005). Globalization and Welfare States, u: Vivekanandan, B.; Kurian, N. (ur.), Welfare States and the Future, Palgrave Macmillan, New York, 2005., str. 62.

${ }^{6}$ Greve, B., What is Welfare and Public Welfare?, u: Greve, B. (ur.), The Routledge Handbook of the Welfare State, Routledge, London - New York, 2019., str. 6.

7 Urdarević, B.; Radulović, Z., Глобализација и концепт социјалних права, Srpska politička misao, Vol. 35, br. 1, 2012., str. 173.
} 
pristup naglašava važnost globalne razine za lokalnu, ${ }^{8}$ što implicira utjecaj globalnih procesa na pojedine identitete, kulturne kodove i značenja koja pojedinci pridaju svijetu. ${ }^{9}$

Strukturu globalnog i umreženog svijeta predstavlja njena suvremena epistema, ogledana kroz pravila i norme prenaglašenog tržišnog fundamentalizma, globalne ekonomije i „marketinškog zavođenja“. ${ }^{10}$ Suvremeno društvo naziva se i umreženim društvom (engl. the network society) koje se prema Castellsu temelji na trima ključnim procesima: kulturnim pokretima 1960-ih, informatičkoj revoluciji 1970-ih te restrukturaciji kapitalizma 1980-ih godina. Upravo je umreženo društvo pomoglo stvoriti i održati globalno tržište. ${ }^{11}$ Pritom se neoliberalna paradigma a priori prihvaća kao ideologijski obrazac globalnog povezivanja, s obzirom da zagovara ideal samoregulirajućeg tržišta klasičnog liberalizma, a manifestira se kao ideologija, sustav vladanja i niz određenih politika. ${ }^{12}$ To znači etabliranje institucija i praksi koje su orijentirane prema tržištu koje potom preuzima vodstvo nad njima. ${ }^{13} \mathrm{~S}$ druge strane, kako bi se tako postavljena globalna struktura reproducirala, ona koristi sisteme koji su prethodno navedeni kao elementi makro i mikro razine.

Institucionalna struktura makro razine ima dva primarna cilja: konstitucionalnu transformaciju društva (restrukturaciju državne vlasti i vladinih ovlasti) i redistribuciju društvenih obligacija. Ostvarenje zahtjeva međunarodnih financijskih institucija dovodi do de facto odricanja država od njihovih ovlasti i mogućnosti upravljanja i/ili reguliranja tržišnih struktura, što rezultira decentralizacijom, dekoncentracijom, devolucijom i deregulacijom. Na mezo razini globalnog sustava dolazi do interakcije regionalnih udruženja, u čijim je temeljima ideja neograničenog tržišta (poput EU ili NAFTA-e), koja donose strateške odluke za vlastite članove, što nužno znači diskriminiranje ne-članova. ${ }^{14}$ Naposljetku, na mikro razini ističe se stvaranje i perpetuiranje globalnih socijalnih prostora habitusa (mentalnih struktura kroz koje se percipiraju i klasificiraju društvene strukture svijeta), s diferenciranim vrstama kapitala koji, za razliku od aktera na makro i mezo razini, izravno utječu na svakodnevne živote pojedinaca. ${ }^{15}$

Prvu i dominantnu sferu umreženog društva čine zemlje „jezgre“" (npr. Ujedinjeno Kraljevstvo, Francuska, Kanada, Sjedinjene Američke Države) koje upravljaju i održavaju međunarodnu ekonomiju te su domaćini dominantnih institucionalnih infrastruktura koje perpetuiraju svjetsku strukturu, ${ }^{16}$ a time i proces globalizacije. Za razliku od slabije razvijenih zemalja (zemalja u razvoju), tržišnih gospodarstava u nastajanju i post-tranzicijskih zemalja, razvijene zapadne države nisu suočene s pritiscima međunarodnih financijskih organizacija koji bi direktno utjecali na njihovu autonomiju u izboru i provođenju javnih politika. lako je i ovdje prisutan neizravan utjecaj financijskih institucija na javne politike s ciljem smanjenja opsega poslijeratne socijalne države druge polovice 20. stoljeća, takav je utjecaj ograničenog dosega

\footnotetext{
8 Lowi, T. J., Naš milenij: politička znanost sučeljuje se s globalnom korporacijskom privredom, Politička misao, Vol. 38, br. 3, 2001., str. 62-65.

${ }_{9}$ Castells, M., An introduction to the information age, City, Vol. 2, br. 7, 1997., str. 16.

10 Delić, Z., Globalizacija, moć i politika znanja: jedanaest antiteza o globalizaciji, Filozofska istraživanja, Vol. 29, br. 1, 2009., str. 34.

11 Castells, cit., str. 7.

12 Steger, M. B.; Roy, R. K., Neoliberalism - A Very Short Introduction, Oxford University Press, Oxford, $2010 .$, str. 11.

13 Cerny, P. G.; Menz, G.; Soederberg, S., Different Roads to Globalization: Neoliberalism, the Competition State, and Politics in a More Open World, u: Soederberg, S.; Menz, G.; Cerny, P. G. (ur.), Internalizing Globalization : The Rise of Neoliberalism and the Decline of National Varieties of Capitalism, Palgrave Macmillan, New York, 2005., str. 12.

14 Lowi, cit., str. 66-69.

15 Bourdieu, P., Social Space and Symbolic Power, Sociological Theory, Vol. 7, br. 1, 1989., str. 17-18.

16 Wallerstein, I., World-systems Analysis - An Introduction, Duke University Press, Durham - London, 2006., str. 17-18.
} 
s obzirom da su te zemlje razvijene demokracije te su vladine politike podložne kritikama opozicije i utjecajima interesnih grupacija, tj. demokracija predstavlja prepreku provođenju globalne neoliberalne ideologije. ${ }^{17}$

S druge strane, „polu-periferiju“ čine zemlje (npr. Brazil, Kina, Španjolska, Portugal) koje se nastoje zaštiti od prelaska u potpunu periferiju vođenjem protekcionističkih ekonomskih politika. Ovdje valja spomenuti i tržišna gospodarstva u nastajanju (ponajprije zemlje Azije i Latinske Amerike) suočene $s$ "uvjetovanim zajmovima“ međunarodnih financijskih organizacija (ponajprije IMF-a i WB-a). ${ }^{18} \mathrm{U}$ tim su zemljama financijska otvorenost i dug privatnog sektora prvenstveni uzročnik ekonomske krize i destabilizacije nacionalnih gospodarstava, s obzirom da im je za izlazak iz krize potrebna financijska pomoć međunarodnih financijskih organizacija uvjetovana provođenjem neoliberalnih gospodarskih reformi proizišlih iz tzv. Washingtonskog konsenzusa. Iz toga proizlazi dihotomija zahtjeva postavljenih pred donositelje javnih politika. Naime, izloženost svjetskom tržištu povećava nesigurnost, potkopava postojeće programe socijalne sigurnosti te time apostrofira potrebu za snažnijim sustavom socijalne zaštite, dok su, nasuprot tome, ekonomski poremećaji, ograničenost resursa, mjere štednje i ideologija privatizacije usmjereni protiv razvijanja sveobuhvatnih programa socijalnog blagostanja. ${ }^{19}$

U trećoj sferi nalaze se zemlje „periferije“ koje ovise o ekonomskoj aktivnosti svjetske jezgre, što se osobito ističe kroz djelovanje međunarodnih organizacija koje prisiljavaju periferiju na odabir određenog "modela“ ekonomskih politika. ${ }^{20}$ Tako slabije razvijene zemlje (zemlje u razvoju), uz oblike socijalne zaštite prisutne i u razvijenim zemljama (npr. pružanje javnih usluga obrazovanja, zdravstvene zaštite i stanovanja), obilježava niz njima karakterističnih socijalnih programa (npr. subvencije, kontrola cijena, paketi hrane) ključnih za održanje dohodaka i životnog standarda. Upravo su na smanjenje i/ili uklanjanje potonjih mjera usmjereni zahtjevi IMF-a i WB-a, u okviru programa stabilizacije i strukturne prilagodbe, kao uvjeti za davanje ili reprogramiranje zajmova. Usprkos različitim odgovorima kreatora domaćih politika na takve zahtjeve, ostaje činjenica da je time oslabljena nacionalna autonomija u samostalnom vođenju ekonomskih i socijalnih politika, a provođenje takvih mjera ("rezova“) rezultiralo je, ponekad drastičnim, padom životnog standarda i porasta siromaštva i isključenosti, dok su gospodarstva slabije razvijenih zemalja snažnije integrirana (te izložena svim pogodnostima i rizicima) u sustav svjetskoga tržišta. ${ }^{21}$

Slično je stanje i u tranzicijskim zemljama iz socijalizma u demokraciju i tržišno gospodarstvo koje se suočavaju s ranjivošću uslijed "otvaranja" gospodarstava, utjecajem međunarodnih financijskih organizacija te rastakanjem sustava socijalne sigurnosti. Specifičan kontekst demokratske i ekonomske tranzicije, i prateće teškoće, dodatno naglašava činjenica (iz socijalizma naslijeđenih) razvijenih sustava socijalne zaštite. Pomoć u provedbi tranzicijskih reformi morala je doći sa Zapada (kao alternative dotadašnjem socijalističkom nasljeđu), zajedno s dominantnom neoliberalnom ideologijom te je takav pristup (prema principu tzv. šok-terapije) rezultirao financijskom liberalizacijom, konvertibilnošću valuta te naglim pripuštanjem tržišnih elemenata u nacionalne ekonomije. Takve mjere, uparene sa slabostima

\footnotetext{
17 Mishra, cit., str. 70-72.

18 Wallerstein, cit., str. 28-30.

19 Mishra, cit., str. 65-66 i 68.

20 Wallerstein, cit., str. 55.

21 Mishra, cit., str. 64-65.
} 
naslijeđenim iz socijalističkog razdoblja, rezultirale su snažnim smanjenjem proizvodnje, visokom razinom nezaposlenosti, oštrim padom plaća te znatnim porastom ekonomskih nejednakosti, siromaštva $i$ isključenosti. Istovremeno su oblici socijalne zaštite specifični socijalizmu smanjeni ili u potpunosti napušteni u pokušaju strukturalne prilagodbe programima socijalnog osiguranja zemalja Zapada. ${ }^{22}$

I Republika Hrvatska u posljednjem desetljeću prošloga stoljeća suočila se s prijelazom iz ranijeg socijalističkog u demokratski i tržišni poredak, u trenutku kada je globalizacija „općenito nametnula nova pravila razvoja nacionalnih gospodarstava", a kreatori ekonomskih politika "sve više prihvaćaju neoliberalni model razvoja s otvorenim ekonomijama, minimalnim državnim intervencijama i slobodnim tržištima (...) kao jedini učinkoviti pristup novoj globalnoj ekonomiji“.23 Imajući na umu prirodu procesa tranzicije vođenog neoliberalnim idejama, Teodorovići ${ }^{24}$ upozorava na potrebu iznalaženja alternative, tzv. srednjeg puta, koji ne bi bio suprotan temeljnim postulatima tržišnog poslovanja, ali bi istovremeno uspješno pridonosio ostvarenju drugih ciljeva razvitka društvene i državne zajednice. Upravo se u tome, pronalasku trećeg puta između socijalističke i neoliberalne krajnosti, ogleda značaj i uloga demokratskih i socijalnih država 21. stoljeća (o čemu više infra). Nasuprot tome, Šonje i Vujčić25 ističu kako većina kritika slobodnog tržišta i liberalnih ideja proizlazi iz pogrešnih predodžbi o naravi tranzicijskoga procesa, pri čemu neuspjesi tranzicije ne proizlaze iz uvođenja "slobodnoga tržišta i političke demokracije", već suprotno, iz neuspjeha realizacije temeljnih postulata liberalizma. Takvo je stajalište moguće prihvatiti isključivo s aspekta dogmatskog opredjeljenja tržišnom fundamentalizmu i profitu kao niti vodilji državnih politika i društvenih interesa. U stvarnosti, društva karakterizira pluralizam interesa te je neprihvatljiva tvrdnja kako „liberalizam koji želi biti pretvoren u akciju ekonomske politike ne bi trebao biti osjetljiv na činjenicu da tržišta ponekad ne uspijevaju, ili da ponekad stvaraju tako velike nejednakosti u raspodjeli dohotka koje dugoročno mogu usporiti ekonomski rast" ${ }^{\prime 26}$ Takvo je stajalište rezultat redukcionističkog poimanja demokracije i državne zajednice u kojoj ne može i ne smije postojati tek jedan cilj (ekonomski), kojem bi sve bilo podređeno. Stoga ga je potrebno kategorički odbaciti.

\section{Restrukturcija ekonomskih nejednakosti kao odraz neoliberalne paradigme}

Globalizacija se često shvaća kao socijalni proces koji teži sveobuhvatnosti i jedinstvenosti svijeta stvaranjem trgovačkih blokova, globalnih tvrtki i globalne ekonomije. ${ }^{27}$ Uzroci ovih procesa pronalaze se u dugoročnim procesima mijenjanja ekonomije (s prelaskom od kejnzijanske države dobrobiti do tačerizma i reganizma), ideologije (koja je neoliberalna i zahtijeva privatizaciju s niskom ulogom države u ostvarivanju dobrobiti) i tehnologije (s kompjuterizacijom, digitalizacijom i sustavima transporta). ${ }^{28}$

\footnotetext{
22 lbid., str. 68-70.

${ }^{23}$ Teodorović, I., Tranzicijski proces u globalnoj okolini, u: Meštrović, M. (ur.), Globalizacija i njene refleksije u Hrvatskoj, Ekonomski institut Zagreb, Zagreb, 2001., str. 133.

24 Ibid., str. 134.

25 Šonje, V.; Vujčić, B., ,"Liberalizam“ u vođenju ekonomske politike, u: Meštrović, M. (ur.), Globalizacija i njene refleksije u Hrvatskoj, Ekonomski institut Zagreb, Zagreb, 2001., str. 149-150.

26 lbid., str. 162.

27 Lončar, J., Globalizacija - Pojam, nastanak i trendovi razvoja, Geoadria, Vol. 10, br. 1, 2005., str. 91-92.

28 Šporer, Ž., Controversies of Globalization, Revija za sociologiju, Vol. 31, br. 3-4, 2000., str. 169-171.
} 
Skeptička perspektiva se može označiti globalnim nominalizmom, odnosno stavom kako globalizacija u stvarnosti ne postoji te kako se globalna ekonomija nije promijenila u odnosu na prošle periode. To se objašnjava isticanjem manjeg dijela prihoda koje ukupno ostvaruje vanjska trgovina. S druge strane, radikali u okviru globalnog realizma naglašavaju stvarne posljedice globalizacijskih procesa. Nacije su izgubile mogućnost utjecaja na događaje, a globalna razmjena je ravnodušna spram nacionalnih granica. ${ }^{29}$ Transformacionalizam, s druge strane, ne pobija objektivnu činjenicu globalizacijskih procesa, već naglašava promjene socijalnog, političkog i ekonomskog tipa, ${ }^{30}$ ali s ciljem popravljanja onih neprihvatljivih poput ekonomskih nejednakosti.

Naime, globalna ideologija je ideologija neoliberalizma čiji je credo tržište koje obuhvaća i uključuje cijelo društvo potpunim podređivanjem pojedinaca tržištu te sa što manjim ili nikakvim državnim intervencijama. ${ }^{31}$ lako je ideal slobodnog tržišta usmjeren k ostvarivanju slobode, ta sloboda nema moralna i zakonska ograničenja, što tržištu ostavlja kratkoročne i pojedinačne ciljeve, s opasnim zanemarivanjem dugoročnih i društvenih posljedica, ${ }^{32}$ poput bitke s ekonomskim nejednakostima. Ekonomski aspekt globalizacije odnosi se na činjenicu da multinacionalne korporacije, stječući dobit i integrirajući svijet, utječu na globalne gospodarske procese. One to čine tako što nadziru svjetske resurse, kapital i tehnologiju. Političkopravni aspekt predstavlja smanjena državna suverenost (osobito u području financija) kao posljedica pristupanja država međunarodnim ugovorima i organizacijama. Tako nastaje globalno upravljanje koje vrši pritisak na vlade država, a što ograničava nacionalni suverenitet. ${ }^{33}$ Kako navodi Kostadinov: , [k]onsolidacija državnih odnosa u međunarodnim organizacijama (...) i stvaranje snažnih elemenata transnational statehooda (...), na regionalnim i globalnim razinama može se opisati kao stvaranje jedne vrste globalne liberalne države pomoću koje je već dobro razvijeno globalno i javno pravo podređeno kapitalu sklonom privatnom pravu, pravni formalizam (...) je zamijenjen pravnom dinamičnošću, a pravno obvezujuće formalno pravilo pravno neobvezujućim neformalnim pravilom“. ${ }^{34}$ Shodno tome, globalizaciju je primjerenije redefinirati kao dinamički proces kojim se kapitalizam, kao struktura modernosti, uz informacijsku tehnologiju, filozofiju racionalizma i liberalizma sve izrazitije širi svijetom. ${ }^{35}$ Iz pozadine ovih aspekata, moguće je razaznati navedenu neprihvatljivu restrukturaciju globalnog društva, jer je ona u suštini restrukturacija ekonomskih nejednakosti.

Društvene nejednakosti, kao ustaljeni obrasci diferenciranja moći, sredstava, usluga i privilegija, kreiraju ekonomsku nejednakost pojavom nove globalne ekonomije što potvrđuju provedena istraživanja u naprednim industrijskim i postindustrijskim društvima. ${ }^{36}$ Ekonomska nejednakost je posljedica svjetskog stanja u kojem manji dio populacije prisvaja najviše koristi od ekonomskog napretka, dok se najveći dio populacije suočava s obrnutom

\footnotetext{
29 Giddens, A., Globalizacija, Diskrepancija, Vol. 1, br. 2, 2000., str. 2-3.

30 Kaluđorđević, Ž., Poimanje globalizacije, Filozofska istraživanja, Vol. 29, br. 1, 2009., str. 24.

31 Letunić, S.; Dragičević, M., Vladajući neoliberalni model razvoja, Naše more, Vol. 62, br. 2, 2015., str. 65-66.

32 Drašković, M., Globalna financijska kriza i neoliberalna dogma, Ekonomija, Vol. 16, br. 1, 2009., str. 129.

33 Lončar, cit., str. 95-96.

34 Kostadinov, B., Vladavina prava - Backsliding ili globalni kraj liberalne demokracije?, u: Bačić, A. (ur.), Ustavne promjene i političke nagodbe: Republika Hrvatska između ustavne demokracije i populizma, Hrvatska akademija znanosti i umjetnosti, Zagreb, 2021., str. 375.

35 Kukoč, M., Liberal Philospohy and Globalization, Synthesis philosophica, Vol. 24, br. 1, 2009., str. 66.

${ }^{36}$ O'Rand, A. M., Social Inequality, u: Borgatta, E. F. (ur.), Encyclopedia of Sociology, Second Edition, Vol. 4, Macmillan Reference USA, New York, 2000., str. 2690-2691.
} 
situacijom. To znači kako se događa kontinuirana redistribucija nacionalnih bogatstava i dohodaka prema vrhu socijalne piramide. ${ }^{37}$ Tako, zahvaljujući supra opisanoj makro razini provedbe ekonomskog povezivanja svijeta, ${ }^{38}$ neoliberalni oblik globalizacije predstavlja „sofisticiranu inačicu hegemonizma", u kojoj je moć i bogatstvo u rukama malobrojne elite, odnosno međunarodnih tržišnih snaga. ${ }^{39}$ Globalne financijske organizacije perpetuiraju neoliberalne vrijednosti putem instrumenata i preporuka poput tzv. Washingtonskog konsenzusa, koji inzistira na fiskalnoj disciplini, liberalizaciji kamatnih stopa, trgovine i inozemnih izravnih investicija te privatizaciji i deregulaciji. ${ }^{40}$ Navedeno zapravo označava ukidanje državnih i zakonskih prepreka uspostavljanjem globalne vladavine bez države (tzv. statless global governance). ${ }^{41}$ Politika međunarodnih institucija je time politika jednog ekonomskog modela kojeg nastoje proširiti zahvaljujući nezaustavljivom procesu globalizacije, što (nažalost) isključuje alternativu ili druge modele tržišnih društava. ${ }^{42}$

Na mezo razini riječ je o korporacijama koje se manifestiraju kroz repetitivna tržišna djelovanja. ${ }^{43}$ Šireći se i zadobivajući moć, korporacije u nekim aspektima nadomještaju političku vlast nacionalne države i kontroliraju ekonomske odnose u svijetu ${ }^{44}$ a protok kapitala koji omogućuju nameće ograničenja radnicima, zajednicama i državama. ${ }^{45}$ Rezultat toga je globalizirana ekonomija čiji su sistemi proizvodnje snažno povezani, nadilazeći granice pojedinih država i tržišta, a nacionalna država više ne predstavlja samostalnu, autonomnu i nezavisnu cjelinu. ${ }^{46}$ Globalizacija i širenje svjetskoga tržišta dovodi do nastanka tzv. kompetitivne države koja smanjuje troškove u svrhu povećanja međunarodne konkurencije domaćih poduzeća. ${ }^{47}$ Ona nije dovoljno moćna da se suprotstavi silama tržišta, što znači da je njena uloga znatno promijenjena ${ }^{48}$ te se od nje zahtijeva uklanjanje prepreka međunarodnoj trgovini, prihvaćanje privatizacije, fleksibilizacija tržišta te smanjenje socijalnih troškova. ${ }^{49} 50$

Ekonomska nejednakost među državama svijeta je multidimenzionalna te, iako su sve zemlje uključene u proces globalizacije, ne uspijevaju se sve uključiti na globalno tržište (premda neoliberalizam ističe tzv. jednakost šansi). Također, dugotrajan utjecaj neoliberalne paradigme etablirao je države pobjednice i gubitnice, a intervencija globalne financijske strukture je gurnula milijune ljudi u siromaštvo. ${ }^{51}$ Svijet se raspodijelio u trgovačke blokove (mezo

37 Odobaša, R., "Nova nejednakost" - Izvori i štetne posljedice rastuće imovinske i dohodovne nejednakosti, Pravni vjesnik, Vol. 28, br. 2, 2012., str. 61-62.

${ }^{38}$ Lowi, cit., str. 62.

39 Jošt, M., Globalizacija: ekonomski problemi i patenti za život, Sociologija sela, Vol. 38, br. 149-150, 2000. , str. 408.

40 Kesner-Škreb, M., Washingtonski konsenzus, Financijska teorija i praksa, Vol. 28, br. 2, 2004., str. $251-252$.

${ }^{41}$ Crnković, A., Gubitak socijalne kohezije kao trošak neoliberalne politike, Crkva u svijetu, Vol. 41, br. 2, $2006 .$, str. 248.

42 Milardović, A., Globalizacija kao obilježje suvremenoga svijeta, Riječki teološki časopis, Vol. 31, br. 1, $2008 .$, str. 7.

43 Lowi, cit., str. 63.

44 Bušljeta, A., Globalizam - Ideologija Globalizacije?, Socijalna ekologija, Vol. 19, br. 2, 2010., str. 133.

${ }^{45}$ Crotty, J.; Epstein, G.; Kelly, P., Multinational corporations in the neo-liberal regime, u: Baker, D.; Epstein, G.; Pollin,

R. (ur.), Globalization and Progressive Economic Policy, Cambridge University Press, Cambridge, 1998., str. 143.

46 Kaluđorđević, cit., str. 25.

47 Urdarević; Radulović, cit., str. 172.

48 Haslam, P. A., The Firm Rules: multinational corporations, policy space and neoliberalism, Third World Quarterly, Vol. 28, br. 6, 2007., str. 1167.

49 Karlić, I., Dvoznačnost fenomena globalizacije - Za globalizaciju solidarnosti, Filozofska istraživanja, Vol. 29, br. 1, 2009., str. 91-92.

50 Mikro razina proizlazi iz prethodne dvije, a tiče se lokalnih manifestacija globalizacijskih procesa i induktivne refleksivnosti društva naspram njih te se u tom smislu mogu spomenuti anti-globalizacijski pokreti, Milardović, cit., str. 10.

51 Jošt, cit., str. 408. 
razina), a neke države su propustile svoju priliku s obzirom da njihova ekonomija, bez obzira na kvalitetu ekonomskih politika, ne može dostići razvijene države. ${ }^{52}$ Proizlazi da inozemne investicije, privatizacija i liberalizacija tržišta štete ranjivima, dok učvršćuju i favoriziraju one koji su već u prednosti. ${ }^{53}$ Odnosno, kako kompeticija postaje norma, države s većim ulaganjima u, programe dobrobiti" nalaze se u nepovoljnom položaju u odnosu na one koje pružaju samo osnovnu zaštitu. ${ }^{54}$ Time se globalizacija može predstaviti kao fenomen koji pogoršava već postojeće probleme nejednakosti i siromaštva unutar zemalja i na međunarodnoj razini. ${ }^{55}$

Iz navedenog proizlaze značajni izazovi za suočavanje država s nejednakostima, a konkretno u poljima koja se tiču mogućih financijskih kriza, nerazmjernog tehnološkog razvoja (bogate zemlje razvijaju tehnologiju, dok se u siromašne seli industrija), fleksibilizacije na tržištu rada (smanjenje broja stalno zaposlenih i umanjenje prava nezaposlenih te, posljedično, povećanje dugotrajne nezaposlenosti) te demografskih trendova (starenje stanovništva i pad nataliteta). ${ }^{56}$ Moguće je zaključiti kako globalne ekonomske nejednakosti nastaju zbog potreba vlada država pobjednica, dok se države gubitnice podređuju interesima međunarodnih korporacija koje žele ući na tržište zemalja u razvoju i eksploatirati ga. ${ }^{57}$

Stoga je od neizmjerne važnosti spoznaja o utjecaju politika unutar državnih granica, ${ }^{58}$ jer se direktno suprotstavlja širenju i restrukturaciji neoliberalne paradigme kao jedinog mogućeg modela razvoja.

\section{Predanost ideji socijalne države kao temelju alterglobalizacijskog pristupa}

lako su globalizacijski procesi ireverzibilni, upravo uslijed rastućih ekonomskih nejednakosti treba naglasiti kako neoliberalizam nije njena nužna ideologija u ekonomskom povezivanju svijeta. Potrebno je postaviti pitanje o mogućnostima, pretpostavkama i modalitetima ostvarenja globalizacije solidarnosti, pravde, ljudskih prava i odgovornosti kako bi se postigao adekvatan alterglobalizacijski odgovor. ${ }^{59}$ Posebno se ističe potreba za globalizacijom solidarnosti, koja prvenstveno proizlazi iz posljedica djelovanja neoliberalizma koji ima inhibirajući učinak na nacionalne države u zaštiti vladavine prava, ljudskih prava, demokracije, slobode i dostojanstva, ${ }^{60}$ iz razloga što se bilo kakav državni intervencionizam smatra negativnim jer navodno sprječava ekonomski rast i stvaranje poslova, kao i bilo kakav oblik socijalne zaštite koju pruža socijalna država. ${ }^{61}$ Učinci neoliberalizma najčešće se očituju kroz povećanje nejednakosti u raspodjeli dohotka te degradaciju kvalitete života, a posebno za

\footnotetext{
52 Grgurić, I., Globalizacija, rast, nejednakost i siromaštvo, Financijska teorija i praksa, Vol. 28, br. 2, 2004., str. $242-243$.

53 Kohl, R., Introduction, u: Kohl, R. (ur.), Globalisation, Poverty and Inequality, OECD, Paris, 2003., str. 14.

54 Ang, A. P., Globalization and Its Impact on the Welfare State Concept in Developed and Developing Countries, Estudios de Deusto, Vol. 66, br. 1, 2018., str. 129.

55 Henry, K.; O'Brien, T., Globalisation, Poverty and Inequality: Friends, Foes or Strangers?, The Australian Economic Review, Vol. 36, br. 1, 2003., str. 3.

56 Pavlišić, P., Društvo na putu sraza: povijesni prikaz i potreba za razvojem pravednije nove ekonomije, Ekonomska misao i praksa, Vol. 25, br. 1, 2016., str. 222.

57 Kohl, cit., str. 14.

58 Henry; O'Brien, cit., str. 17-18.

59 Veljak, L., Neumitnost globalizacije, nužnost alternative i pitanje o odgovornosti, Filozofska istraživanja, Vol. 29, br. 1, 2009., str. 12.

60 Karlić, cit., str. 93.

${ }^{61}$ Navarro, V., Neoliberalism, "Globalization“, Unemployment, Inequalities, and the Welfare State, International Journal of Health Services, Vol. 28, br. 4, 1998., str. 608.
} 
one države koje ne raspolažu dostatnim sredstvima i utjecajem kako bi se zaštitile. ${ }^{62}$ Takav stav zagovornika neoliberalizma direktno ide protiv globalnog morala i etike, zanemarujući osnovna načela ljudske egzistencije poput sreće, blagostanja, zadovoljavajućih životnih uvjeta, pravde i slobode. ${ }^{63}$

Socijalna država je svaka država koja ima centralnu ulogu u pružanju usluga dobrobiti, a to čini sustavima javnih usluga i benefita potrebnih za zadovoljenje osnovnih egzistencijalnih potreba. Dodatno, uloga socijalnih država se širi te obuhvaća i uklanjanje potencijalnih rizika s kojima se pojedinac suočava tijekom životnog vijeka. ${ }^{64}$ Tako je jedna od zadaća socijalne države i uklanjanje ili barem smanjenje razine ekonomskih nejednakosti u društvu. Štoviše, opisane korjenite restrukturacije globalnog svijeta i ekonomskih nejednakosti dodatno potvrđuju nužnost ostvarenja socijalnih ciljeva. Najvažniji sustav je još uvijek nacionalna socijalna država jer „su još uvijek pouzdani štitovi protiv valova globalizacije“, s obzirom da međunarodna zajednica nema učinkovite mjere, a ni mogućnosti za zaštitu od socijalne isključenosti. ${ }^{65}$ Ona provodi svojevrsno uravnoteživanje odnosa moći tako što djeluje putem državnog osiguranja besplatnih i subvencioniranih usluga. Upravo zato, socijalna "država ne zadire u liberalna načela, ali si uzima za pravo [naplatiti] njihovu socijalnu cijenu." ${ }^{166}$ Suprotno, politike vođene postulatima neoliberalne paradigme komodificiraju usluge i benefite dobrobiti, odnosno oni postaju roba na tržištu koja se može kupiti, zanemarujući njihovu ovisnost o pojedinačnim dohocima ili ekonomskim resursima, ${ }^{67}$ dodatno degradirajući osnovni element društvenog života (socijalne pravde) koji osigurava "da svatko dobije ono što je dužan dobiti“68

Valja naglasiti kako zagovornici neoliberalne ideologije često ističu neprofitabilnost mjera socijalne države. Nasuprot tome, pokazalo se da je u periodima kada su na vlasti bili zagovornici neoliberalnih javnih politika ekonomski rast bio manji (ili je stagnirao) u odnosu na razdoblja državnog intervencionizma u javne politike. Tako je u Sjedinjenim Američkim Državama i Ujedinjenom Kraljevstvu, gdje su neoliberalne politike najsnažnije izražene (uspoređujući trendove od 1973. do 1997. godine), zabilježen manji ekonomski rast, nego u državama $s$ reguliranim tržištem rada i ekstenzivnom socijalnom zaštitom. ${ }^{69}$ Dolazi se do zaključka da socijalna država nije neekonomična, već da ideologija neoliberalizma, koja usmjerava globalizaciju, prisiljava države s razvijenom socijalnom zaštitom (zbog međunarodnog tržišnog nadmetanja) na redukciju mjera socijalne sigurnosti kako ne bi izgubile strane ulagače. Drugim, riječima, ograničavajući autonomiju nacionalnih država, osobito u sferi socijalne politike, globalizacija dovodi do rastakanja socijalne države (što se ponajbolje ogleda kroz povećanje stope nezaposlenosti i siromaštva). ${ }^{70}$

\footnotetext{
62 Niggle, C. J., Globalization, Neoliberalism and the Attack on Social Security, Review of Social Economy, Vol. 61, br. 1, 2003., str. 61.

63 Strahovnik, V., Globalization, Globalized Ethics and Moral Theory, Synthesis philosophica, Vol. 24, br. 2, 2009. , str. 213.

64 Giddens, A., Sociology - Sixth Edition, Polity Press, Cambridge, 2009., str. 507.

65 Sing, H., Utjecaj globalizacije na manje zemlje te uloga manjih zemalja u procesu globalizacije: primjer socijalne politike i socijalnog rada, Revija za socijalnu politiku, Vol. 9, br. 1, 2002., str. 29.

${ }^{66}$ Kalanj, R., Liberalni i socijalnodržavni princip (Nepomirljivost ili konvergencija?), Revija za sociologiju, Vol. 22, br. 2, 1991., str. 296.

67 Giddens, Sociology..., cit., str. 507.

68 Alwin, D. F., Social Justice, u: Borgatta, E. F. (ur.), Encyclopedia of Sociology, Second Edition, Vol. 4, Macmillan Reference USA, New York, 2000., str. 2695.

69 Navarro, cit., str. 611-612.

70 Urdarević; Radulović, cit., str. 173.
} 
Također, vlade donose politike s ciljem privlačenja investitora na ulaganje u njihove zemlje, razmjenjujući socijalno osiguranje za viši dohodak. ${ }^{71} \mathrm{U}$ konačnici, „društvo koje želi biti stabilno i napredno zapravo si ne smije dopustiti ukidanje mehanizama i smanjivanje sredstava za socijalne intervencije države ".72

Mnoštvo ustava suvremenih država utemeljuje ih kao socijalne te usmjerava k ostvarenju socijalne pravde i sigurnosti. ${ }^{73}$ Socijalna država na sebe preuzima odgovornost za osiguranje osnovnih egzistencijalnih potreba građana, a njene politike usmjerene su na djelatnosti države u socijalnoj sferi. ${ }^{74}$ Takvo određenje je u skladu s pronalaženjem srednjeg puta (alterglobalizacije), tj. sinteze demokratske, pravne i socijalno pravedne države koja će biti prihvatljiva alternativa nereguliranom kapitalizmu i nedemokratskom socijalizmu. ${ }^{75}$ Država blagostanja (socijalna država), između ostaloga, naglašava neodrživost postojećeg neoliberalnog modela pozivajući se na trenutnu situaciju u svjetskoj ekonomiji, a kao odgovor predviđa kombiniranu socijalno-tržišnu varijantu. ${ }^{76}$ Tako socijalna država svoj legitimitet temelji na osiguranju egzistencijalnog minimuma i dostupnosti javnih službi, a to ponajprije čini poreznim prihodima, prikupljenim s osnove svojeg fiskalnog (i poreznog) suvereniteta. ${ }^{77}$ Međutim, poreznu državu ne treba a priori izjednačiti sa socijalnom, s obzirom da socijalni karakter porezne države ovisi o načinu ubiranja poreznih prihoda (ponajprije uvažavanju načela ekonomske snage), kao i svrsi njihova trošenja. ${ }^{78}$ Progresivnim oporezivanjem bogatih te slobodnim pristupom zdravstvenim, obrazovnim i kulturalnim uslugama, zajamčenim mirovinama, naknadama za nezaposlenost, socijalnim stanovanjem, kao i zabranom diskriminacije siromašnih i onih koji žive od rada, moguće je smanjiti trend rasta dohodovne i imovinske nejednakosti. ${ }^{79}$ Nasuprot tome, privatizacija javnih (i socijalnih) usluga opravdava se, primjerice, smanjivanjem javne potrošnje, što je izravno protiv načela egalitarnosti, jer pojedinci nikada nemaju jednaku kupovnu snagu (te je u takvoj konstelaciji pristup javnim uslugama vezan uz (financijske) mogućnosti, a ne potrebu korisnika usluge). ${ }^{80}$

Upravo se u sferi oporezivanja ponajprije očituje tzv. pesimistički pogled na globalizacijske procese, s obzirom da postavljaju rastuća ograničenja političkim granama vlasti u provođenju poreznih politika koje smatraju primjerenima i potrebnima. U demokratskim državama, takva ograničenja pojavljuju se ujedno i kao ograničenja demokratskog odlučivanja. ${ }^{81}$

\footnotetext{
71 Kapstein, E. B.; Milanović, B., Odgovor na globalizaciju - Socijalna politika u novim tržišnim ekonomijama, Revija za socijalnu politiku, Vol. 9, br. 1, 2002., str. 70-71.

72 Odobaša, cit., str. 73.

73 Cindori, S.; Kuzelj, V., Exemplis discimus: reafirmacija vrijednosti i redefinicija sadržaja socijalne države u novom stoljeću, Zbornik Pravnog fakulteta Sveučilišta u Rijeci, Vol. 40, br. 2, 2019., str. 824-825.

74 Puljiz, V.; Bežovan, G.; Šućur, Z.; Zrinščak, S., Socijalna politika - Povijest - Sustavi - Pojmovnik, Pravni fakultet Sveučilišta u Zagrebu, Zagreb, 2005., str. 6.

75 Kuzelj, V., Apologija socijalne države nasuprot institucionalizaciji nejednakosti u neoliberalnom poretku, Paragraf, Vol. 3, br. 1, 2019., str. 60.

76 Cvetićanin, N., Globalna ekonomska kriza i obnavljanje konsenzusa blagostanja, Politička misao, Vol. 47, br. 1, 2010., str. 41-42.

77 Kuzelj, Apologija socijalne države..., cit., str. 60. i 66-67.

78 Kuzelj, V., Porezna pravednost: Conditio sine qua non socijalne države, Pravnik, Vol. 52, br. 103, 2018., str. 99-100.

79 Odobaša, cit., str. 73-74.

80 Esping-Andersen, G., Positive-Sum Solutions in a World of Trade-Offs?, u: Esping-Andersen, G. (ur.), Welfare States in Transition : National Adaptations in Global Economies, SAGE Publications, London, 1996., str. 263.

81 Roxan, I., Limits to Globalisation: Some Implications for Taxation, Tax Policy, and the Developing World, LSE Law, Society and Economy Working Papers, br. 3, 2012., str. 19.
} 
Evidentno je kako veća povezanost i međuovisnost ima značajan utjecaj na porezne sustave te porezna baza poreza na dohodak i bogatstvo postaje geografski mobilnija i, samim time, osjetljivija na razlike u njihovom poreznom tretmanu u različitim državama. Istovremeno je otežano utvrđivanje porezne obveze i ubiranje poreza na aktivnosti koje se odvijaju u drugim državama, tj. izvan porezne jurisdikcije nacionalne države. ${ }^{82}$ Pritom argument o ograničenju fiskalnog suvereniteta nacionalnih država ovisi o dva elementa: postojanju tzv. poreznog nadmetanja (engl. tax competition) između država, koje će u stvarnosti dovesti do smanjenja efektivnih poreznih stopa na tzv. mobilni kapital; te o činjenici koliko je kapital doista mobilan (ako je visoko mobilan, ali ne u potpunosti, dovest će do sniženja efektivne porezne stope; ako je u potpunosti mobilan, efektivna porezna stopa past će na nulu). ${ }^{83}$ Stoga nacionalne države u suvremenosti trebaju pronaći način kako zadržati autonomiju u jednoj od najvažnijih sfera državnih ovlasti, naime, suverenitet u fiskalnim i poreznim pitanjima.

Upravo u kontekstu ostvarenja i zaštite ustavne ideje socijalne države valja istaknuti opasnosti utjecaja globalizacije na nacionalne ekonomije, ogledane kroz posljedice umreženog neoliberalnog tržišta, ali i kroz prelijevanje cikličkih kriza (svojstvenih kapitalizmu) iz razvijenih gospodarstava u sve države. Tako je globalna financijska kriza iz 2008. godine rezultirala neposrednim angažmanom nacionalnih socijalnih država u uklanjanju njezinih uzroka i neposrednih posljedica, pri čemu se ističe značajna uloga mjera unutar poreznog sustava u svrhu ublažavanja nepovoljnih procesa i posljedica u gospodarskom i društvenom životu. ${ }^{84}$ Aktualna globalna kriza COVID-19 bolesti postavlja nove izazove pred nacionalne fiskalne sustave, s obzirom na dugotrajne gospodarske i financijske posljedice poduzetih protu-pandemijskih mjera, ogledane kroz porast deficita državnog proračuna i javnog duga uz istovremeno povećanje javnih rashoda uslijed dodijeljenih poticaja i olakšica te poreznih rasterećenja. ${ }^{85}$ Pritom valja istaknuti posebnost aktualne krize u odnosu na prethodnu, s obzirom da je uslijed recesije iz 2008. godine bila ugrožena realizacija pojedinih socio-ekonomskih prava, dok je suočavanje s trenutnom situacijom zahtijevalo ograničenje kako socio-ekonomskih prava, tako i određenih temeljnih građanskih sloboda. ${ }^{86}$ Socijalni troškovi protu-pandemijskih mjera, ponajprije tzv. zaključavanja (engl. lockdown), naglašavaju izvanrednost situacije, s obzirom da ,s jedne strane, kriza dovodi do naglog smanjenja fiskalnih prihoda, a istodobno je neophodan veliki fiskalni napor da bi se očuvalo poduzetništvo te ublažio rast siromaštva i nejednakosti“. ${ }^{87}$ Promatrano u povijesnom kontekstu, svako je izvanredno stanje (npr. rat, depresija i dr.) rezultiralo povećanjem opsega i intenziteta aktivnosti države, dok se nakon krize udio javne potrošnje nikad ne bi vratio u prijašnje okvire. ${ }^{88}$ Razvidno je da će i u post-

82 Owens, J., Globalisation: The Implications for Tax Policies, Fiscal Studies, Vol. 14, br. 3, 1993., str. 23.

83 Roxan, cit., str. 20.

84 Jelčić, B., Promjene u udjelu poreza u bruto društvenom proizvodu, u: Arbutina, H.; Rogić Lugarić, T. (ur.), Spomenica Prof. dr. sc. Juri Šimoviću, Pravni fakultet Sveučilišta u Zagrebu/Studijski centar za javnu upravu i javne financije, Zagreb, 2017., str. 160.

85 Žunić Kovačević, N., Posljedice i učinci pandemije bolesti COVID-19 na fiskalni sustav i oporezivanje, Zbornik radova Pravnog fakulteta u Splitu, Vol. 58, br. 2, 2021., str. 488.

${ }^{86}$ Horvat Vuković, A.; Kuzelj, V., Constitutionality During Times of Crisis: Anti-pandemic Measures and Their Effect on the Rule of Law in Croatia, u: Bevanda, V. (ur.), ERAZ 2020 - Knowledge Based Sustainable Development, Conference Proceedings, Association of Economists and Managers of the Balkans, Beograd, 2020., str. 60.

87 Žunić Kovačević, cit., str. 486.

88 Samuelson, P. A.; Nordhaus, W. D., Economics, McGraw-Hill Irwin, New York, 2010., str. 304. 
pandemijskim uvjetima pred nacionalne države biti postavljen zadatak suočavanja s ekonomskim posljedicama globalne zdravstvene krize.

Potrebno je naglasiti ulogu (ustavnog) sudstva u zaštiti socijalnih prava, što je posebno aktualno u kontekstu krize i ocjene kriznih mjera ${ }^{89}$ političkih grana vlasti (ponajprije zakonodavne). Pritom, kroz ocjenu ustavnosti kriznog zakonodavstva (ustavni) sudovi ujedno odlučuju „o samoj ideji normativnosti ustava“ te posljedično utječu na povjerenje u ustav i ustavni poredak, istovremeno se suočavajući s odlukama koje bi mogle promijeniti „profil“ suda: bilo kroz pokoravanje ranije uspostavljenoj doktrini, bilo kroz promjenu u interpretaciji s obzirom na novonastale okolnosti. ${ }^{90} \mathrm{~S}$ druge strane, s obzirom na potrebu brze reakcije na krizu (koja nije svojstvena parlamentima kao deliberativnim predstavništvima građana) dolazi do situacije u kojoj prijedlozi kriznog zakonodavstva od strane izvršne vlasti bivaju ishitreno i bez rasprave potvrđivani od strane parlamenta, lišavajući ga njegove tradicionalne uloge (što ne samo da umanjuje kvalitetu zakonskih rješenja, već rezultira rastakanjem identiteta zakonodavne vlasti). ${ }^{91}$ Takve implicitne izmjene ustavne strukture rezultiraju gubitkom legitimiteta političke klase te rastućim, gotovo kroničnim, nepovjerenjem u državne institucije. ${ }^{92}$

\section{Umjesto zaključka}

Iz supra navedenih razloga, nacionalne socijalne države moraju pronaći prihvatljiv način suočavanja s uvjetima globaliziranog tržišta (i njemu svojstvenih kriza), kako bi osigurale dostojan život građana, ali i očuvale vjeru u temeljne principe svojih ustavnih poredaka. U suštini to znači provođenje konzistentnih socijalnih politika u nacionalnim okvirima koje moraju naglasiti stvaranje solidarnih društveno-ekonomskih odnosa te rezultirati nivelacijom ekstremnih i rastućih ekonomskih nejednakosti, ${ }^{93}$ ali i aktivnu (ustavno)sudsku ulogu u zaštiti socijalnih prava kao inherentnih demokratskim i socijalnim državama 21. stoljeća. „Naime, socijalna prava predstavljaju zajedničko, civilizacijsko pitanje, kako za razvijene

\footnotetext{
${ }^{89} \mathrm{U}$ kontekstu RH valja navesti odluku Ustavnog suda Republike Hrvatske o suglasnosti s Ustavom tzv. "kriznog poreza", koja se ističe jednom od najprjepornijih odluka u hrvatskoj ustavnosudskoj praksi. Detaljnije vidi Cindori, S.; Kuzelj, V., Socijalni aspekt kriznoga poreza: fiskalni instrument ili devijacija poreznog sustava?, Ekonomska misao $i$ praksa, Vol. 27, br. 2, 2018., str. 479-502.

90 Contiades, X.; Fotiadou, A., How Constitutions Reacted to the Financial Crisis, u: Contiades, X. (ur.), Constitutions in the Global Financial Crisis : A Comparative Analysis, Ashgate, Farnham, 2013., str. 10. Ustavnosudske odluke o socijalnim pravima općenito su obilježene prijeporima te ustavni sudovi pri odlučivanju o socijalnim pravima često balansiraju između potrebe zaštite ustavnih socijalnih prava s jedne, te poštovanja širokog spektra zakonodavne diskrecije pri uređenju socijalne materije s druge strane. Tako Ustavni sud Republike Hrvatske u svojoj praksi potvrđuje normativni značaj ustavnog koncepta socijalne države, Cindori; Kuzelj, Exemplis discimus..., cit., str. 834-835., ali istovremeno uvodi razlikovanje između navedenog koncepta i elemenata koji bi ga trebali ostvarivati, naime socijalnih prava i poreznog sustava. Uslijed toga dolazi do neadekvatne zaštite ustavnog koncepta socijalne države, detaljnije vidi Miloš, M.; Kuzelj, V., Ostvarenje i zaštita ustavnog ideala porezne pravednosti u svjetlu zahtjeva socijalne države, Zbornik radova Pravnog fakulteta u Splitu, Vol. 58, br. 4, 2021., str. 1101-1120. Pritom posebno zabrinjava mogućnost da „u sferi gospodarskih i socijalnih prava (osobito u pogledu fiskalnog i poreznog zakonodavstva) suzdržanost [Ustavnog suda Republike Hrvatske] prije ukazuje na dobrovoljnu pasivnost prema političkim granama vlasti (poglavito zakonodavnoj), nego na doktrinarnu suzdržanost prema izboru ekonomskih i socijalnih politika kao implikaciju koncepcije ekonomske neutralnosti [Ustava Republike Hrvatske] ili na dosljednost u primjeni načela ustavnosudskog samoograničenja i doktrine o političkim pitanjima", Miloš; Kuzelj, ibid., str. 1120.

91 Contiades; Fotiadou, ibid., str. 16.

92 Ibid., str. 19.

93 Kvartuč, D., Ekonomske nejednakosti u uvjetima globalizacije, Pravnik, Vol. 55, br. 107, 2021., str. 237.
} 
tržišne ekonomije, tako i za zemlje tranzicije“.94 Socijalna pravda, kao jedno od osnovnih organizacijskih načela razvijenih država, ima značajnu ulogu u očuvanju globaliziranog tržišnog sustava, s obzirom da "uz vladavinu prava i demokratsku participaciju, konstituira jedan od fundacijskih elemenata liberalnog demokratskog poretka".95

\section{LITERATURA}

1. Alwin, D. F. 2000. Social Justice. U: Borgatta, E. F. ur. Encyclopedia of Sociology, Second Edition, Vol. 4. New York: Macmillan Reference USA, 2695-2711.

2. Ang, A. P. 2018. Globalization and Its Impact on the Welfare State Concept in Developed and Developing Countries. Estudios de Deusto, Vol. 66(1), 117-132.

3. Barišić, P., 2008. Does Globalization Threaten Democracy?. Synthesis philosophica, Vol. 46(2), 297-303.

4. Bourdieu, P. 1989. Social Space and Symbolic Power. Sociological Theory, Vol. 7(1), 14-25.

5. Bušljeta, A. 2010. Globalizam - Ideologija Globalizacije?. Socijalna ekologija, Vol. 19(2), 127-150.

6. Castells, M. 1997. An introduction to the information age. City, Vol. 2(7), 6-16.

7. Cerny, P. G., Menz, G. i Soederberg, S. 2005. Different Roads to Globalization: Neoliberalism, the Competition State, and Politics in a More Open World. U: Soederberg, S., Menz, G. i Cerny, P. G. ur. Internalizing Globalization : The Rise of Neoliberalism and the Decline of National Varieties of Capitalism. New York: Palgrave Macmillan, 1-30.

8. Cindori, S. i Kuzelj, V. 2018. Socijalni aspekt kriznoga poreza: fiskalni instrument ili devijacija poreznog sustava?. Ekonomska misao i praksa, Vol. 27(2), 479-502.

9. Cindori, S. i Kuzelj, V. 2019. Exemplis discimus: reafirmacija vrijednosti i redefinicija sadržaja socijalne države u novom stoljeću. Zbornik Pravnog fakulteta Sveučilišta u Rijeci, Vol. 40(2), 823-843.

10. Contiades, X. i Fotiadou, A. 2013. How Constitutions Reacted to the Financial Crisis. U: Contiades, X. ur. Constitutions in the Global Financial Crisis : A Comparative Analysis. Farnham: Ashgate, 9-59.

11. Crnković, A. 2006. Gubitak socijalne kohezije kao trošak neoliberalne politike. Crkva u svijetu, Vol. 41(2), 245-254.

12. Crotty, J., Epstein, G. i Kelly, P. 1998. Multinational corporations in the neo-liberal regime. U: Baker, D., Epstein, G. i Pollin, R. ur. Globalization and Progressive Economic Policy. Cambridge: Cambridge University Press, 117-143.

13. Cvetićanin, N. 2010. Globalna ekonomska kriza i obnavljanje konsenzusa blagostanja. Politička misao, Vol. 47(1), 31-54.

14. Delić, Z. 2009. Globalizacija, moć i politika znanja: jedanaest antiteza o globalizaciji. Filozofska istraživanja, Vol. 29(1), 31-50.

\footnotetext{
94 Urdarević; Radulović, cit., str. 181.

95 Elsenhans, H., A World Economy Based on the Welfare State Principle, u: Vivekanandan, B.; Kurian, N. (ur.), Welfare States and the Future, Palgrave Macmillan, New York, 2005., str. 41.
} 
15. Drašković, M. 2009. Globalna financijska kriza i neoliberalna dogma. Ekonomija, Vol. 16(1), 127-148.

16. Elsenhans, H. 2005. A World Economy Based on the Welfare State Principle. U: Vivekanandan, B. i Kurian, N. ur. Welfare States and the Future. New York: Palgrave Macmillan, 41-61.

17. Esping-Andersen, G. 1996. Positive-Sum Solutions in a World of Trade-Offs?. U: EspingAndersen, G. ur. Welfare States in Transition : National Adaptations in Global Economies. London: SAGE Publications, 256-267.

18. Giddens, A. 2000. Globalizacija. Diskrepancija, Vol. 1(2), 59-66.

19. Giddens, A. 2009. Sociology - Sixth Edition. Cambridge: Polity Press.

20. Greve, B., 2019. What is Welfare and Public Welfare?. U: Greve, B. ur. The Routledge Handbook of the Welfare State. London, New York: Routledge, 5-12.

21. Grgurić, I. 2004. Globalizacija, rast, nejednakost i siromaštvo. Financijska teorija i praksa, Vol. 28(2), 235-250.

22. Haslam, P. A. 2007. The Firm Rules: multinational corporations, policy space and neoliberalism. Third World Quarterly, Vol. 28(6), 1167-1183.

23. Henry, K. i O'Brien, T. 2003. Globalisation, Poverty and Inequality: Friends, Foes or Strangers?. The Australian Economic Review, Vol. 36(1), 3-21.

24. Horvat Vuković, A. i Kuzelj, V. 2020. Constitutionality During Times of Crisis: Anti-pandemic Measures and Their Effect on the Rule of Law in Croatia. U: Bevanda, V. ur. ERAZ 2020 - Knowledge Based Sustainable Development, Conference Proceedings, Beograd: Association of Economists and Managers of the Balkans, 59-65.

25. Jelčić, B. 2017. Promjene u udjelu poreza u bruto društvenom proizvodu. U: Arbutina, $H$. i Rogić Lugarić, T. ur. Spomenica Prof. dr. sc. Juri Šimoviću. Zagreb: Pravni fakultet Sveučilišta u Zagrebu/Studijski centar za javnu upravu i javne financije, 147-162.

26. Jošt, M. 2000. Globalizacija: ekonomski problemi i patenti za život. Sociologija sela, Vol. 38(149-150), 407-417.

27. Kalanj, R. 1991. Liberalni i socijalnodržavni princip (Nepomirljivost ili konvergencija?). Revija za sociologiju, Vol. 22(2), 293-306.

28. Kaluđorđević, Z. 2009. Poimanje globalizacije. Filozofska istraživanja, Vol. 29(1), 15-29.

29. Kapstein, E. B. i Milanović, B. 2002. Odgovor na globalizaciju - Socijalna politika u novim tržišnim ekonomijama. Revija za socijalnu politiku, Vol. 9(1), 65-78.

30. Karlić, I. 2009. Dvoznačnost fenomena globalizacije - Za globalizaciju solidarnosti. Filozofska istraživanja, Vol. 29(1), 87-106.

31. Kesner-Škreb, M. 2004. Washingtonski konsnezus. Financijska teorija i praksa, Vol. 28(2), 251-254.

32. Kohl, R. 2003. Introduction. U: Kohl, R. ur. Globalisation, Poverty and Inequality. Paris: OECD, 11-18.

33. Kostadinov, B. 2021. Vladavina prava - Backsliding ili globalni kraj liberalne demokracije?. U: Bačić, A. ur. Ustavne promjene i političke nagodbe : Republika Hrvatska između ustavne demokracije i populizma. Zagreb: Hrvatska akademija znanosti i umjetnosti, 365-378.

34. Kukoč, M. 2009. Liberal Philosophy and Globalization. Synthesis Philosophica, Vol. 24(1), 65-78. 
35. Kuzelj, V. 2018. Porezna pravednost: Conditio sine qua non socijalne države. Pravnik, Vol. 52(103), 99-108.

36. Kuzelj, V. 2019. Apologija socijalne države nasuprot institucionalizaciji nejednakosti u neoliberalnom poretku. Paragraf, Vol. 3(1), 59-84.

37. Kvartuč, D. 2021. Ekonomske nejednakosti u uvjetima globalizacije. Pravnik, Vol. 55(107), 229-239.

38. Letunić, S. i Dragičević, M. 2015. Vladajući neoliberalni model razvoja. Naše more, Vol. 62(2), 65-71.

39. Lončar, J. 2005. Globalizacija - Pojam, nastanak i trendovi razvoja. Geoadria, Vol. 10(1), 91-104.

40. Lowi, T. J. 2001. Naš milenij: politička znanost sučeljuje se globalnom korporacijskom privredom. Politička misao, Vol. 38(3), 60-81.

41. Milardović, A. 2008. Globalizacija kao obilježje suvremenog svijeta. Riječki teološki časopis, Vol. 31(1), 5-14.

42. Miloš, M. i Kuzelj, V. 2021. Ostvarenje i zaštita ustavnog ideala porezne pravednosti u svjetlu zahtjeva socijalne države. Zbornik radova Pravnog fakulteta u Splitu, Vol. 58(4), 1101-1120.

43. Mishra, R., 2005. Globalization and Welfare States. U: Vivekanandan, B., Kurian, N. ur. Welfare States and the Future. New York: Palgrave Macmillan, 62-77.

44. Navarro, V. 1998. Neoliberalism, „Globalization“, Unemployment, Inequalities, and the Welfare State. International Journal of Health Services, Vol. 28(4), 607-682.

45. Niggle, C. J. 2003. Globalization, Neoliberalism and the Attack on Social Security. Review of Social Economy, Vol. 61(1), 51-71.

46. Odobaša, R. 2012. „Nova nejednakost“ - Izvori i štetne posljedice rastuće imovinske i dohodovne nejednakosti. Pravni vjesnik, Vol. 28(2), 59-77.

47. O'Rand, A. M. 2000. Social Inequality. U: Borgatta, E. F. ur. Encyclopedia of Sociology, Second Edition, Vol. 4. New York: Macmillan Reference USA, 2690-2695.

48. Owens, J. 1993. Globalisation: The Implications for Tax Policies. Fiscal Studies, Vol. 14(3), 21-44.

49. Pavlišić, P. 2016. Društvo na putu sraza: povijesni prikaz i potreba za razvojem pravednije nove ekonomije. Ekonomska misao i praksa, Vol. 25(1), 217-238.

50. Puljiz, V., Bežovan, G., Šućur, Z. i Zrinščak, S. 2005. Socijalna politika - Povijest - Sustavi Pojmovnik. Zagreb: Pravnik fakultet Sveučilišta u Zagrebu.

51. Roxan, I. 2012. Limits to Globalisation: Some Implications for Taxations, Tax Policy, and the Developing World. LSE Law, Society and Economy Working Papers, (3), 1-47.

52. Samuelson, P. A. i Nordhaus, W. D. 2010. Economics. New York: McGraw-Hill Irwin.

53. Sing, H. 2002. Utjecaj globalizacije na manje zemlje te uloga manjih zemalja u procesu globalizacije: primjer socijalne politike i socijalnog rada. Revija za socijalnu politiku, Vol. 9(1), 23-32.

54. Steger, M. B. i Roy, R. K. 2010. Neoliberalism - A Very Short Introduction. Oxford: Oxford University Press. 
55. Strahovnik, V. 2009. Globalization, Globalized Ethics and Moral Theory. Synthesis philosophica, Vol. 24(2), 209-218.

56. Šonje, V. i Vujčić, B. 2001.„Liberalizam“ u vođenju ekonomske politike. U: Meštrović, M. ur. Globalizacija i njene refleksije u Hrvatskoj. Zagreb: Ekonomski institut Zagreb, 149-164.

57. Šporer, Ž. 2000. Controversies of Globalization. Revija za sociologiju, Vol. 31(3-4), 165-181.

58. Teodorović, I. 2001. Tranzicijski proces u globalnoj okolini. U: Meštrović, M. ur. Globalizacija i njene refleksije u Hrvatskoj. Zagreb: Ekonomski institut Zagreb, 133-148.

59. Urdarević, B. i Radulović, Z. 2012. Глобализација и концепт социјалних права. Srpska politička misao, Vol. 35(1), 169-186.

60. Veljak, L. 2009. Neumitnost globalizacije, nužnost alternative i pitanje o odgovornosti. Filozofska istraživanja, Vol. 29(1), 7-13.

61. Wallerstein, I. 2006. World-systems Analysis - An Introduction, Durham, London: Duke University Press.

62. Žunić Kovačević, N. 2021. Posljedice i učinci pandemije bolesti COVID-19 na fiskalni sustav i oporezivanje. Zbornik radova Pravnog fakulteta u Splitu, Vol. 58(2), 483-499.

Summary

\title{
THE ROLE OF NATIONAL SOCIAL STATES FOR PRESERVATION AND PROTECTION OF SOCIAL VALUES IN THE CONTEXT OF NEOLIBERAL GLOBAL ORDER
}

\begin{abstract}
Globalization, as a process that strives for the universality and singularity of the world, raises the complex question of ways to confront economic inequalities as a consequence of the neoliberal model of world market integration. Bearing in mind the restructuring nature of this process, which takes place on several levels, it is concluded that the resulting relations in the world trade network diminish the importance of the financial sovereignty of national states. Given this, economic inequalities are perpetuated, and the social instruments of national states have been blocked due to networking in the global market that follows the pattern of the neoliberal paradigm. The paper presents the levels at which global market integration takes place (macro, meso, and micro), and highlights the various effects of the globalization process on developed (Western) democracies, emerging market economies, developing countries, and post-transition countries from socialism to democracy. In addition, the impact of economic processes, and crises on the constitutional order of national states is highlighted, which may result in "tacit" changes in the constitutional structures of individual states in the direction of dissolving the role of legislatures (as elected representatives of citizens) in creating economic, fiscal, and social policies. Finally, it is pointed out that, given the impossibility of unified regulation of the world market, mechanisms to combat the negative (social and economic) consequences of the globalization process need to be found within the framework of national states.
\end{abstract}

Keywords: social state, globalization, neoliberalism, economic inequalities, social values. 